\title{
AMS RADIOCARBON DATING OF BONES AT LSCE
}

\author{
$\mathrm{N}$ Tisnérat-Laborde ${ }^{1,2} \bullet \mathrm{H}_{\text {Valladas }}{ }^{\bullet} \cdot$ E Kaltnecker $^{1} \bullet \mathrm{M}^{\text {Arnold }}{ }^{3}$
}

ABSTRACT. In this paper, we explain our routine pretreatment of bone for radiocarbon dating by accelerator mass spectrometry (AMS), based on the specific reaction between amino acids and ninhydrin described by Nelson (1991). The values and uncertainties of the total system background are presented as a function of the carbon sample mass and the reliability of this method is discussed.

\section{INTRODUCTION}

Since the first ${ }^{14} \mathrm{C}$ dates were obtained (Arnold et al. 1951), radiocarbon laboratories have developed many methods of bone pretreatment. Usually, these methods are based on the extraction of the bone organic matter. The extract can consist of the whole collagen (Longin 1971; Brown et al. 1988; Hedges et al. 1989; Law et al. 1989; Kretschmer et al. 1998), a mixture of collagen amino acids (Gillespie et al. 1986; Gurfinkel 1987; Long et al. 1989; Redvers-Newton et al. 1994), specific individual amino acids (van Klinken et al. 1990), or non-collagenous proteins (Ajie et al. 1992). These extracts are oxidized to $\mathrm{CO}_{2}$, then reduced to graphite and dated.

For more than 10 years at the Laboratoire des Sciences du Climat et de l'Environnement (LSCE), we have prepared bone by the method described by Nelson (1991), based on a chemical reaction that extracts $\mathrm{CO}_{2}$ from carboxylic groups of proteinaceous molecules. This chemical treatment is preceded by elemental analyses $(\% \mathrm{~N}, \% \mathrm{C}, \mathrm{C} / \mathrm{N})$ in order to quantify the bone collagen, and, consequently, to determine if the bone is datable.

In this paper, we describe the protocol of bone preparation. We present the blank values obtained on bones from 2 sites, Sclayn and Gerde. Finally, we discuss the reliability of the ${ }^{14} \mathrm{C}$ ages obtained by this method by comparing some of them to other ${ }^{14} \mathrm{C}$ dates available for the same archeological layers. These samples are either charcoal, burnt bones, or bones treated differently.

\section{MATERIAL AND METHOD}

\section{Material}

On the basis of porosity, bone may be classified as cortical bone (also known as compact bone) or trabecular bone (also called cancellous or the spongy part). The cortical bone, which is much denser and less porous than the cancellous bone, is preferred for ${ }^{14} \mathrm{C}$ dating since it is generally less altered by diagenesis.

The fossil bones used to estimate the degree of contamination introduced by our protocol come from 2 sites. Five bones were collected in Scladina Cave (Sclayn, Belgium), under a stalagmitic floor in layer 4A, which was dated by thermoluminescence to approximately 100,000 yr ago (Debenham 1998). Another bone comes from layer $2 b$ of Carrière cave (Gerde, France), which is below a stalagmitic floor and dated to 52,500 yr ago by U/Th (Clot 1987).

\footnotetext{
${ }^{1}$ Laboratoire des Sciences du Climat et de l'Environnement, UMR CEA-CNRS 1572, Avenue de la Terrasse, F-91198

Gif-sur-Yvette, France.

${ }^{2}$ Corresponding author. Email: tisnerat@1sce.cnrs-gif.fr.

${ }^{3}$ Gif-sur-Yvette Tandetron facility, UMS 2004, Avenue de la Terrasse, F-91198 Gif-sur-Yvette, France.
} 


\section{Method}

The protocol used for the bone treatment is summarized in Figure 1.

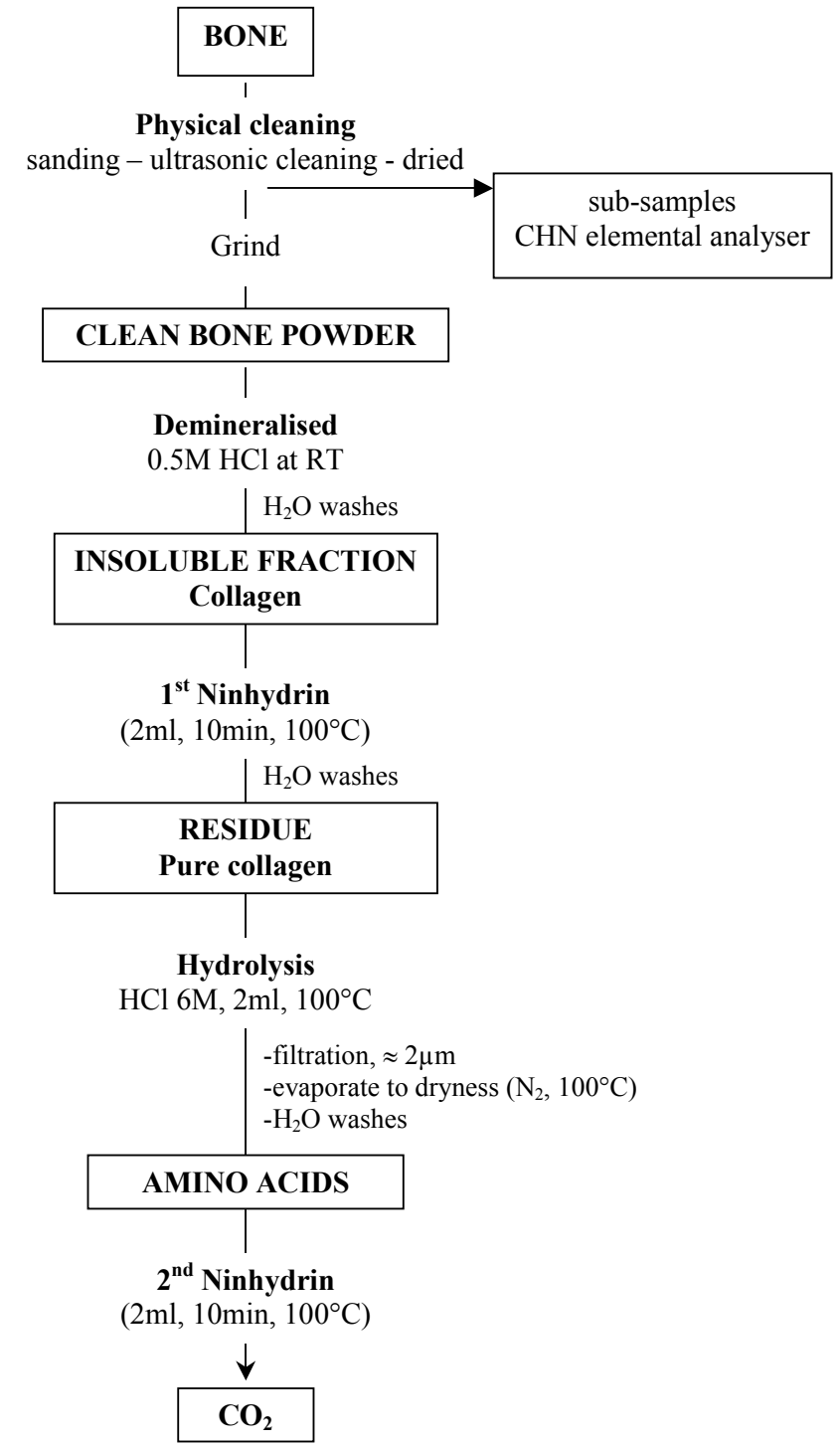

Figure 1 Diagram showing pretreatment steps of bones for AMS ${ }^{14} \mathrm{C}$ dating

Mechanical Treatment and Elemental Analyses

A piece of bone sample $(\sim 1-2 \mathrm{~cm})$ is cleaned mechanically with an airbrasive system with $27 \mu \mathrm{g}$ aluminum oxide to remove superficial contaminants (roots, glue) and the spongy part, which is considered to be the most contaminated.

A sub-sample of approximately $5 \mathrm{mg}$ is drilled out and subjected to elemental analysis. It is introduced in a tin capsule into a Carlo-Erba NA 1500 elemental analyzer. 
The other part of the mechanically cleaned bone (1-3 g) - if it contains enough collagen - is ultrasonically rinsed in Milli-Q water to remove aluminum oxide and dried at $45^{\circ} \mathrm{C}$. This bone is then finely ground in a planetary micro-mill composed of bowls and balls of zirconium oxide $\left(\mathrm{ZrO}_{2}\right)$.

\section{Chemical Treatment}

The powdered bone is repeatedly treated with $0.5 \mathrm{M} \mathrm{HCl}$ and stirred at room temperature to remove carbonates, phosphates, and fulvic acids until the residue becomes colloidal. The acid-insoluble collagenous residue is then rinsed with Milli-Q water until neutral $\mathrm{pH}$ is reached.

Next, $50 \mathrm{mg}$ of ninhydrin (2,2-dihydroxy-1,3-indandione) in a 2-ml sodium citrate buffer ( $\mathrm{pH}=4.8$ ) is added to the residue, which is heated at $100^{\circ} \mathrm{C}$ for $10 \mathrm{~min}$. The ninhydrin reacts specifically with the free amino acids, which come from either degraded collagen or contaminants. The ninhydrin reacts with the $\alpha-\mathrm{NH}_{2}$ of amino acids to give $\alpha$-imino acids, which react with water to give $\alpha$-ceto acids (Moore et al. 1950). These $\alpha$-ceto acids are unstable and release $\mathrm{CO}_{2}$ from the $\alpha$-carboxyl group:

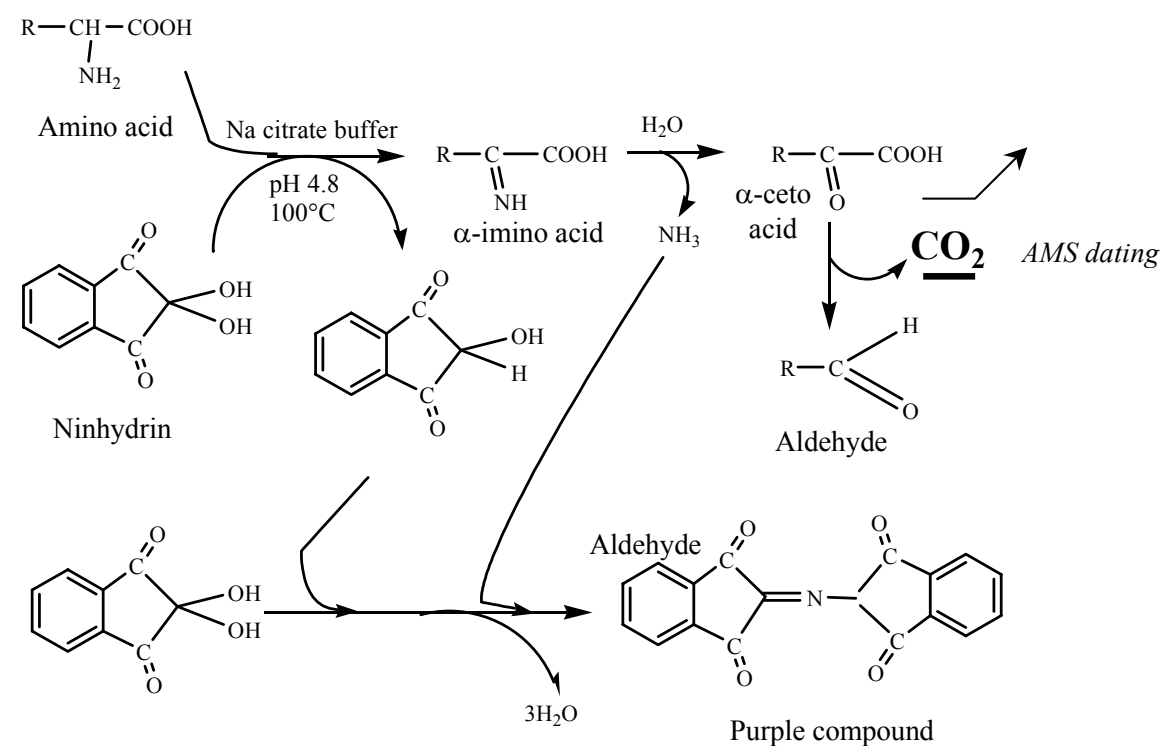

The $\mathrm{CO}_{2}$ is not collected and the residue is rinsed until the solution is decolorized.

Next, this "pure" residue is hydrolyzed to free amino acids with hot acid $\left(\mathrm{HCl} 6 \mathrm{M}\right.$ at $100{ }^{\circ} \mathrm{C}$ overnight). The solution of free amino acids is filtered on a precleaned glass filter and collected in a glass reactor. This filtrate is evaporated at $80^{\circ} \mathrm{C}$ under nitrogen. The free amino acid residue is rinsed 5 times with Milli-Q water, which is then evaporated at $80^{\circ} \mathrm{C}$ under nitrogen.

The reactor is connected to a vacuum line (Figure 2 ) and heated to $100^{\circ} \mathrm{C}$ with heating coils. Once the vacuum reaches $\approx 2.10^{-4} \mathrm{mb}$ after $\sim 2$ days, $2 \mathrm{ml}$ of ninhydrin solution is injected through a septum. The released $\mathrm{CO}_{2}$ is dried by passing through 2 "water traps" $\left(-78^{\circ} \mathrm{C}\right.$, mix of dry ice and ethanol), trapped in a liquid nitrogen trap $\left(-196^{\circ} \mathrm{C}\right)$, quantified into the calibrated volume, and then collected in a glass vial. The entire treatment and the $\mathrm{CO}_{2}$ transformation take more than 8 days. 


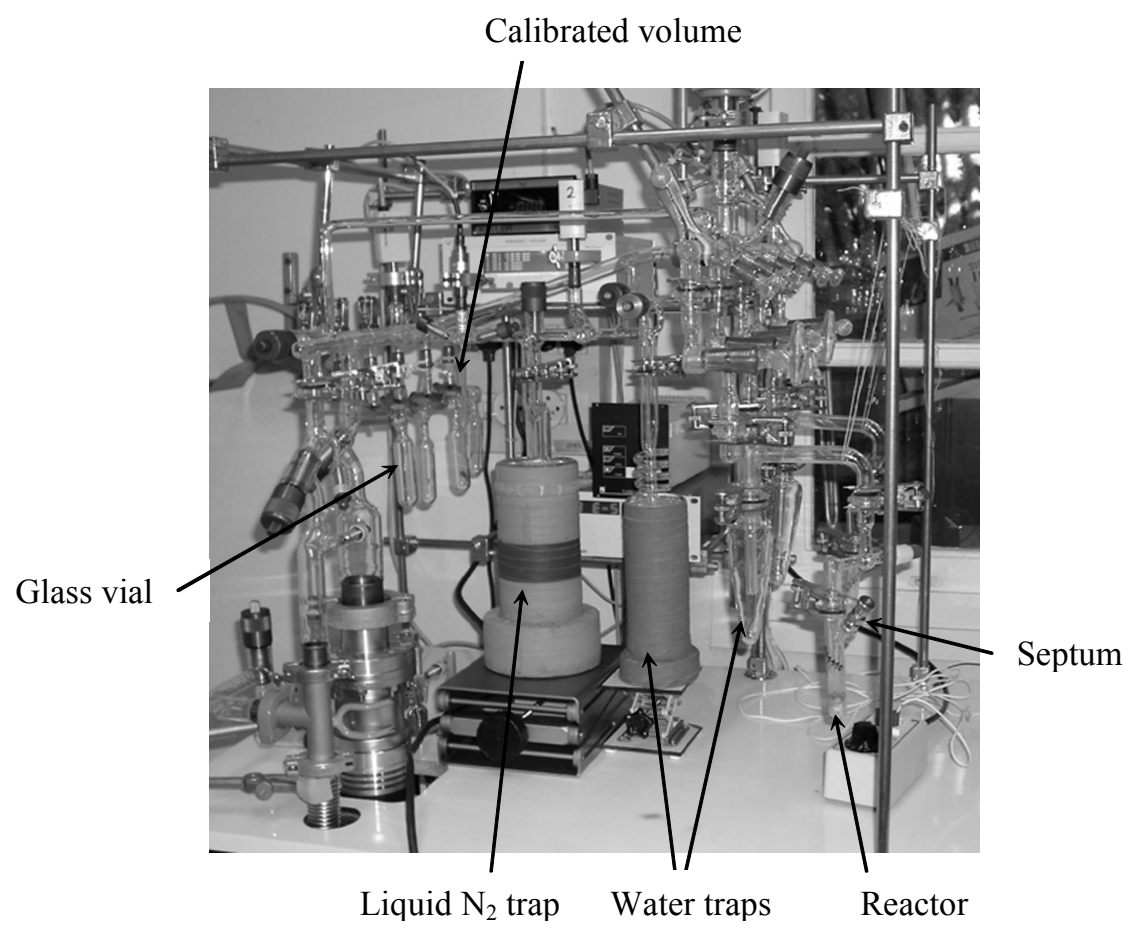

Figure 2 Photograph of the vacuum line

The $\mathrm{CO}_{2}$ was reduced to graphite (Arnold et al. 1989) and the ${ }^{14} \mathrm{C}$ ages were obtained by accelerator mass spectrometry (AMS) at the Gif-sur-Yvette Tandetron Facility (UMS 2004).

\section{RESULTS AND DISCUSSION}

\section{Blanks}

\section{Results of Elemental Analyses}

Several sub-samples were removed from different parts of the Sclayn and Gerde bones for elemental analyses $(\% \mathrm{~N}, \% \mathrm{C}, \mathrm{C} / \mathrm{N})$. The results are reported in Table 1.

Nitrogen concentrations in the Sclayn bones range from $0.57-2.17 \% \mathrm{wt}$, in agreement with previous measurements (Bocherens et al. 1997), and in the Gerde bones from 1.21-2.5\%wt. These nitrogen concentrations in the whole bone give some idea of the quantity of collagen (Hedges et al. 1992; Bocherens et al. 1997; Gillespie et al. 1984; Ambrose 1990; Hedges et al. 1995). Indeed, the quantity of nitrogen ranges from about $4 \%$ in a fresh bone (Stafford et al. 1988; Ambrose 1993) to below $0.2 \%$ in poorly preserved bone, which cannot be dated by the ninhydrin method. With nitrogen amounts ranging from $0.5-2.5 \% \mathrm{wt}$, the Sclayn and Gerde bones contain enough collagen for AMS dating.

The scatter of the nitrogen measurements shows that the diagenesis of the organic matter is not homogeneous within any one bone. The $\mathrm{C} / \mathrm{N}$ ratio of the whole bone can help to estimate the degree of diagenetic alteration. High values (i.e., $>5$ ) indicate extensive diagenesis (deamination) or a high proportion of exogenous carbon (humics). For the Sclayn bones, the $\mathrm{C} / \mathrm{N}$ ratios are statistically similar with a mean value of $4.55 \pm 0.4\left(\mathrm{n}=14 ; \chi^{2} ; \mathrm{P}_{0.05}=9.95 / 22.40\right)$, excluding the value of the 
Table 1 Nitrogen and carbon concentrations in bone, expressed as \% of bone weight (\%wt) and the atomic $\mathrm{C} / \mathrm{N}$ ratio of the Sclayn (SC91-) and Gerde blank bones. The results of the underlined line correspond to the analyses carried out on the spongy part of the bone.

\begin{tabular}{llll}
\hline Sample & $\begin{array}{l}\text { Nitrogen } \\
(\% \mathrm{wt} \pm \Delta)\end{array}$ & $\begin{array}{l}\text { Carbon } \\
(\% \mathrm{wt} \pm \Delta)\end{array}$ & C/N ratio \\
\hline SC91-500G30 & $1.33 \pm 0.14$ & $6.6 \pm 0.3$ & $5.0 \pm 0.8$ \\
& $0.67 \pm 0.07$ & $3.9 \pm 0.2$ & $5.9 \pm 0.9$ \\
SC91-450F28 & $0.69 \pm 0.07$ & $3.1 \pm 0.2$ & $4.4 \pm 0.7$ \\
& $0.57 \pm 0.06$ & $3.0 \pm 0.2$ & $5.3 \pm 0.8$ \\
& $1.33 \pm 0.14$ & $5.2 \pm 0.3$ & $3.9 \pm 0.6$ \\
& $1.02 \pm 0.11$ & $4.5 \pm 0.2$ & $4.4 \pm 0.7$ \\
SC91-503G30 & $0.59 \pm 0.06$ & $3.0 \pm 0.2$ & $5.1 \pm 0.8$ \\
& $0.60 \pm 0.06$ & $3.3 \pm 0.2$ & $5.5 \pm 0.9$ \\
& $\underline{0.60 \pm 0.06}$ & $\underline{5.4 \pm 0.2}$ & $9.0 \pm 1.3$ \\
SC91-588F27 & $2.17 \pm 0.22$ & $8.2 \pm 0.4$ & $3.8 \pm 0.6$ \\
& $0.65 \pm 0.07$ & $3.3 \pm 0.2$ & $5.0 \pm 0.8$ \\
& $1.07 \pm 0.11$ & $4.6 \pm 0.2$ & $4.3 \pm 0.7$ \\
SC91-619F30 & & & \\
& $1.12 \pm 0.12$ & $4.7 \pm 0.2$ & $4.2 \pm 0.6$ \\
& $1.21 \pm 0.13$ & $4.9 \pm 0.2$ & $4.0 \pm 0.6$ \\
Gerde & $0.79 \pm 0.08$ & $4.0 \pm 0.2$ & $5.1 \pm 0.8$ \\
& & & \\
& $1.21 \pm 0.14$ & $4.7 \pm 0.3$ & $3.9 \pm 0.7$ \\
& $2.50 \pm 0.29$ & $8.4 \pm 0.4$ & $3.4 \pm 0.6$ \\
& $1.66 \pm 0.19$ & $6.0 \pm 0.3$ & $3.6 \pm 0.6$ \\
\hline
\end{tabular}

spongy part of sample $\mathrm{SC} 91-503 \mathrm{G} 30 / 3(\mathrm{C} / \mathrm{N}=9)$. This high $\mathrm{C} / \mathrm{N}$ ratio is attributed to the addition of humic contaminants since the nitrogen concentrations are similar within the compact and the spongy parts; the high $\mathrm{C} / \mathrm{N}$ ratio confirms the importance of removing this porous part of the bone. This mean $\mathrm{C} / \mathrm{N}$ ratio of Sclayn bones is approximately equal to the fresh bone (5) and shows the good preservation of these bones. For the Gerde sample, the mean $\mathrm{C} / \mathrm{N}$ ratio is equivalent to $3.58 \pm$ $0.6\left(\mathrm{n}=3, \chi^{2} ; \mathrm{P}_{0.05}=0.4 / 5.99\right)$, and is slightly lower than the $\mathrm{C} / \mathrm{N}$ value in Sclayn. This lower value can be explained by a loss of inorganic carbon (decalcification) during burial. The Gerde bone seems less well preserved than the Sclayn bones.

The nitrogen concentrations show that the Sclayn and Gerde bones contain enough collagen for AMS datings and the $\mathrm{C} / \mathrm{N}$ ratios show their degree of preservation and their non-contamination.

AMS ${ }^{14} \mathrm{C}$ Results

The ${ }^{14} \mathrm{C}$ values of the Sclayn and Gerde bones (Table 2) are presented as a function of the carbon mass in Figure 3. These blank values take into account the chemical pretreatment, the conversion into $\mathrm{CO}_{2}$, the graphitization, and the machine background contaminants. They increase from 0.10 $\mathrm{pMC}$ to $0.80 \mathrm{pMC}$ as the carbon sample size decreases from $2400 \mu \mathrm{g}$ to less than $300 \mu \mathrm{g}$. 
Table $2{ }^{14} \mathrm{C}$ results of the Sclayn (SC91-) and Gerde bones, reported in pMC

\begin{tabular}{lcl}
\hline Sample & Mass $(\mu \mathrm{g})$ & $\begin{array}{l}\text { Fraction modern } \\
\text { pMC } \pm 1 \sigma\end{array}$ \\
\hline SC91-500G30 & 280 & $0.60 \pm 0.07$ \\
& 290 & $0.31 \pm 0.03$ \\
& 950 & $0.15 \pm 0.02$ \\
SC91-450F28 & 1760 & $0.31 \pm 0.07$ \\
SC91-503G30 & 1040 & $0.32 \pm 0.03$ \\
& & \\
& 460 & $0.16 \pm 0.02$ \\
& 460 & $0.18 \pm 0.02$ \\
SC91-588F27 & 970 & $0.66 \pm 0.06$ \\
SC91-619F30 & 1240 & $0.37 \pm 0.04$ \\
& 1270 & $0.24 \pm 0.03$ \\
& & \\
& 2390 & $0.16 \pm 0.02$ \\
& 390 & $0.79 \pm 0.05$ \\
& 660 & $0.28 \pm 0.03$ \\
& 1300 & $0.17 \pm 0.03$ \\
& 1345 & $0.16 \pm 0.03$ \\
Gerde & 1575 & $0.19 \pm 0.03$ \\
& 1630 & $0.22 \pm 0.03$ \\
& 1740 & $0.10 \pm 0.02$ \\
& 1790 & $0.18 \pm 0.02$ \\
& 2050 & $0.10 \pm 0.02$ \\
& 290 & $0.42 \pm 0.06$ \\
& 580 & $0.41 \pm 0.05$ \\
& 990 & $0.30 \pm 0.04$ \\
\hline
\end{tabular}

The data indicate a statistically significant mass dependence relationship, as previously reported by several studies of ${ }^{14} \mathrm{C}$ background (Vogel et al. 1987; Kirner et al. 1995; Brown et al. 1997; Schleicher et al. 1998; Tisnérat-Laborde et al. 2001). By using the least-squares method, the best fit between ${ }^{14} \mathrm{C}$ concentrations and the inverse carbon mass is obtained by:

$$
\mathrm{y}=119.68( \pm 28.59) / \mathrm{x}+0.1295( \pm 0.0486)
$$

where $\mathrm{y}={ }^{14} \mathrm{C}$ concentration (pMC) and $\mathrm{x}=$ carbon mass $(\mu \mathrm{g})$. This increase of the ${ }^{14} \mathrm{C}$ background is due to the addition of $1.3 \mu \mathrm{g}$ of modern carbon $(100 \mathrm{pMC})$ per $\mathrm{mg}$ of sample during the whole process.

All the blank values from Sclayn and Gerde (Figure 3) are consistent, although the $\mathrm{C} / \mathrm{N}$ analyses showed a lower preservation for the Gerde sample. Such agreement indicates the reliability of our protocol.

These blank values are higher than those obtained from the Carrara marble IAEA C-1, which range from $0.06-0.14 \mathrm{pMC}$ as the size decreases from $2400-300 \mu \mathrm{g}$ (Tisnérat-Laborde et al. 2001). The contamination during the chemical treatment and the conversion of bone into $\mathrm{CO}_{2}$ may be responsible for the high blank values since the graphitization and the machine processing are the same for 


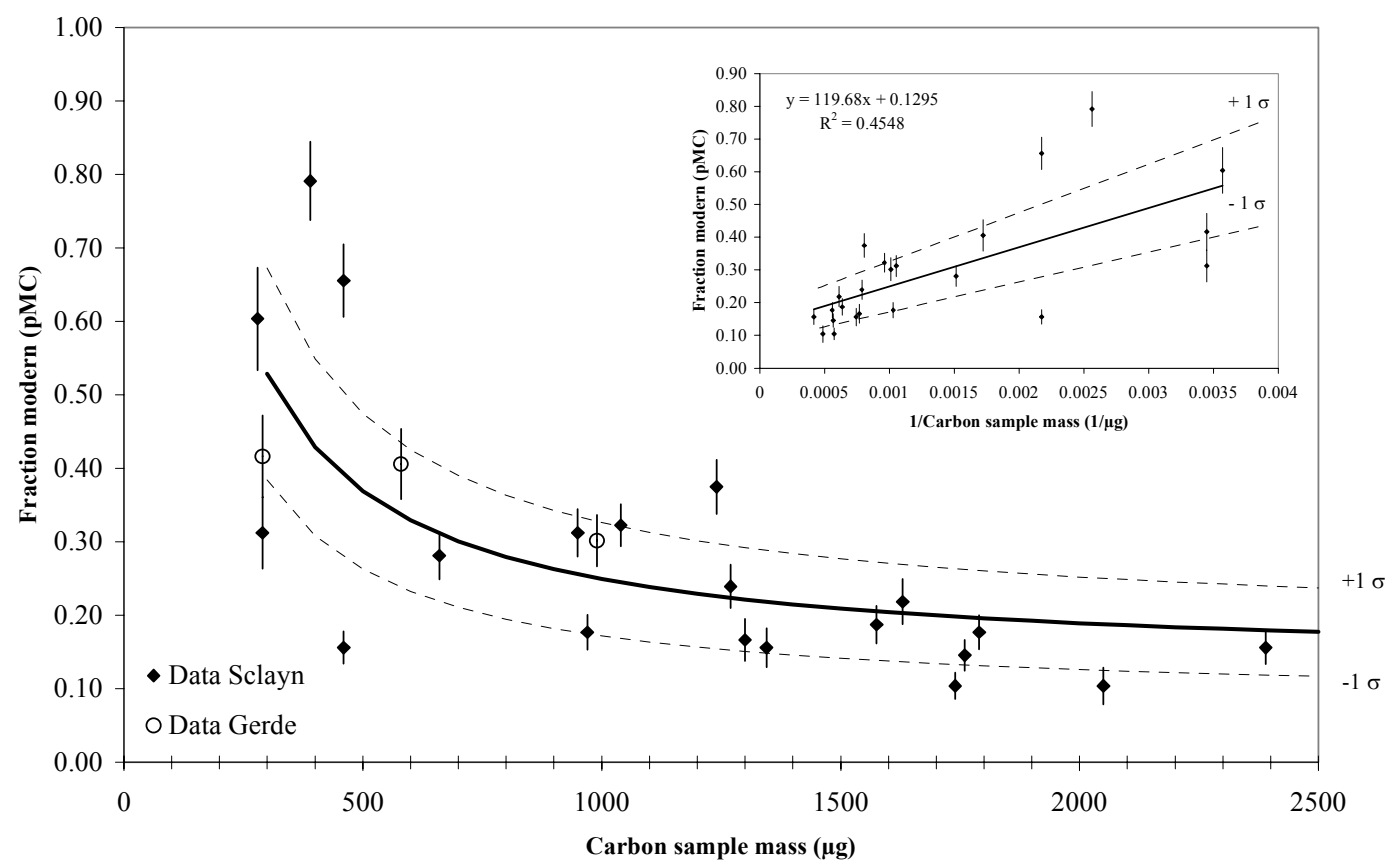

Figure $3{ }^{14} \mathrm{C}$ concentration (pMC) as a function of carbon sample mass $(\mu \mathrm{g})$. The error bars are shown as $\pm 1 \sigma(68 \%$ of overall confidence). The inset small figure is the relation between the inverse carbon sample weight and the ${ }^{14} \mathrm{C}$ concentration (pMC). Dashed lines correspond to the $1 \sigma$ error.

these 2 types of sample. We also reject the intrinsic contamination because the same results were obtained for different bones and different sites. We suspect the vacuum line processes before the conversion stage of the amino acids to $\mathrm{CO}_{2}$ to be responsible for this level of contamination for the following 2 reasons:

1. The pumping is less effective for the bone than for the carbonate (by $\sim 1$ order) because the residue quickly becomes pasty under the vacuum;

2. Atmospheric $\mathrm{CO}_{2}$ may have been introduced during the addition of ninhydrin, either in the form of dissolved $\mathrm{CO}_{2}$ in the ninhydrin or when the septum was perforated.

The ${ }^{14} \mathrm{C}$ ages of bone are calculated using the blank values determined from the mass dependent equation. From this equation, the age limit is about 50,000 BP $(0.2 \pm 0.08 \mathrm{pMC})$ for a carbon mass of $1500 \mu \mathrm{g}$, and about $45,000 \mathrm{BP}(0.37 \pm 0.1 \mathrm{pMC})$ for a carbon mass of $500 \mu \mathrm{g}$.

\section{Reliability of the Method}

The ${ }^{14} \mathrm{C}$ ages of bones treated by the ninhydrin method are compared to those obtained for the same archeological layer on associated organic materials (charcoal, burnt bones) and bones treated by other methods. We use the Chi-squared test statistic to check consistency of these determinations (Ward et al. 1978).

In the first test of reliability, 3 sites (Trois-Frères Cave, Laugerie Haute, and Kozarnika) allowed the comparison of ${ }^{14} \mathrm{C}$ dates of ninhydrin-treated bones with those of associated charcoals or burnt bones. These charcoals or burnt bones underwent the classical AAA treatment. The ${ }^{14} \mathrm{C}$ results of the 3 archeological sites are reported in Table 3 and Figure 4. At Trois-Frères Cave and Laugerie- 
Haute (Delpech et al. 2001; Roque et al. 2001), the burnt bones and bones have consistent ${ }^{14} \mathrm{C}$ ages. The Kozarnika site (Fontugne et al. 2002) reveals the ${ }^{14} \mathrm{C}$ age of the bone to be slightly older than those of the 2 charcoals, but, nevertheless, statistically in agreement.

Table 3 Comparison between ${ }^{14} \mathrm{C}$ dates from bones (ninhydrin method) and from associated charcoals or burned bones (AAA treatment). All ages are given in ${ }^{14} \mathrm{C}$ yr BP (before 1950). Statistical errors are given at $1 \sigma$.

\begin{tabular}{|c|c|c|c|c|c|c|}
\hline Site & Lab nr & Material & $\begin{array}{l}\text { Age } \\
\text { (yr BP) }\end{array}$ & $\begin{array}{l}\text { Error } \\
(1 \sigma)\end{array}$ & Chi-squared test & Reference \\
\hline Trois-Frères Cave & $\begin{array}{l}\text { GifA } 99552 \\
\text { GifA } 99555 \\
\text { GifA } 99550 \\
\text { GifA } 99551 \\
\text { GifA } 99553 \\
\text { GifA } 99554\end{array}$ & $\begin{array}{l}\text { bone } \\
\text { bone } \\
\text { burnt bone } \\
\text { burnt bone } \\
\text { burnt bone } \\
\text { burnt bone } \\
\text { average }\end{array}$ & $\begin{array}{l}14210 \\
13930 \\
14060 \\
13980 \\
14210 \\
14200 \\
\mathbf{1 4 1 0 0}\end{array}$ & $\begin{array}{r}110 \\
110 \\
110 \\
120 \\
110 \\
120 \\
\mathbf{5 0}\end{array}$ & $6.21 / \chi_{6 ; 0.05}^{2}=11.1$ & \\
\hline Laugerie Haute & $\begin{array}{l}\text { GifA } 100634 \\
\text { GrN-4442 } \\
\text { GrN-4495 } \\
\text { Ly-1173 (OxA) } \\
\text { GifA } 100630\end{array}$ & $\begin{array}{l}\text { bone } \\
\text { bone } \\
\text { bone } \\
\text { burnt bone } \\
\text { burnt bone } \\
\text { average }\end{array}$ & $\begin{array}{l}19550 \\
19600 \\
19740 \\
19525 \\
19600 \\
\mathbf{1 9 6 0 0}\end{array}$ & $\begin{array}{r}340 \\
140 \\
200 \\
155 \\
200 \\
\mathbf{8 0}\end{array}$ & $0.75 / \chi^{2}{ }_{5 ; 0.05}=9.49$ & $\begin{array}{l}\text { Delpech \& Riguad } 2001 \\
\text { Roque et al. } 2001\end{array}$ \\
\hline Kozarnika & $\begin{array}{l}\text { GifA } 99662 \\
\text { Gif/LSM- } \\
\text { 10994 } \\
\text { GifA } 101050\end{array}$ & $\begin{array}{l}\text { bone } \\
\text { charcoal } \\
\text { charcoal } \\
\text { average }\end{array}$ & $\begin{array}{l}39310 \\
38700 \\
37170 \\
\mathbf{3 8 0 0 0}\end{array}$ & $\begin{array}{r}1000 \\
1400 \\
700 \\
\mathbf{5 3 0}\end{array}$ & $3.37 / \chi^{2}{ }_{3 ; 0.05}=5.99$ & $\begin{array}{l}\text { Fontugne \& } \\
\text { Tisnérat-Laborde, } \\
\text { in press }\end{array}$ \\
\hline
\end{tabular}

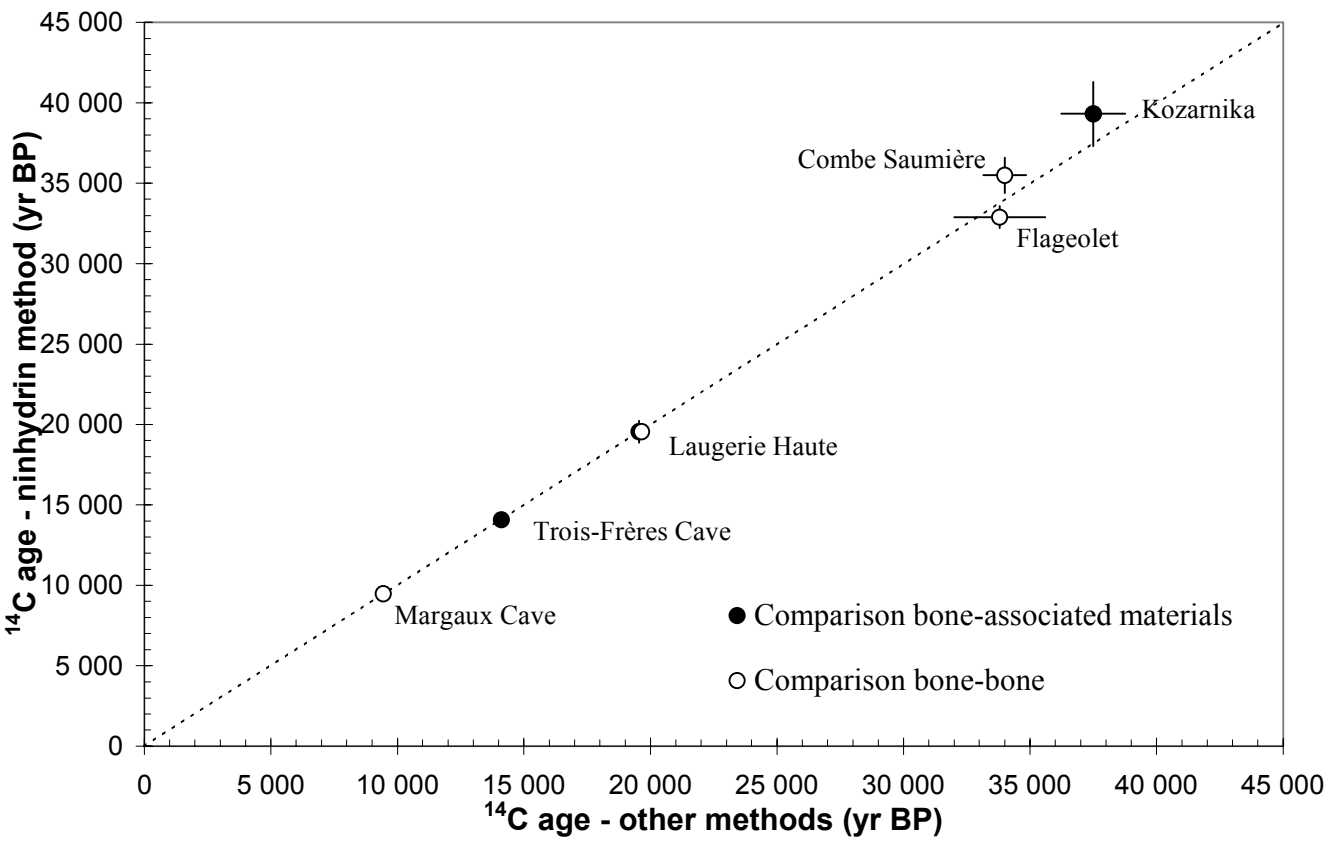

Figure 4 From a same archeological level, the average ${ }^{14} \mathrm{C}$ dates obtained with the ninhydrin method are plotted versus the average ${ }^{14} \mathrm{C}$ ages obtained with the Oxford bone method (open circles) or associated materials (solid circles). The ages are expressed as yr BP. The error bars are shown as $\pm 1 \sigma$ (for 5 of the data points, these error bars are smaller than the symbols). The dotted line is the 1:1 correlation line. 
In the second test, we compared the ${ }^{14} \mathrm{C}$ dates of bones treated by different chemical methods. The results are reported in Table 4 and Figure 4. A comparison with the Oxford method (Hedges et al. 1989; Law et al. 1989) may be made for 3 sites: Margaux Cave, Flageolet, and Combe Saumière (Delpech et al. 2001) (Table 4). A comparison with the Groningen procedure can be done for the site of Laugerie Haute (Table 3). In all cases, the ${ }^{14} \mathrm{C}$ ages are similar whatever the chemical treatment, as previously noted by Nelson (1991).

Table 4 Comparison of ${ }^{14} \mathrm{C}$ ages of bones pretreated by the method used by the Oxford Radiocarbon Laboratory (OxA) and by the ninhydrin method (LSCE, GifA). All ages are given in ${ }^{14} \mathrm{C}$ yr BP (before 1950). Statistical errors are given at $1 \sigma$.

\begin{tabular}{|c|c|c|c|c|c|c|}
\hline Site & Lab nr & Material & $\begin{array}{l}\text { Age } \\
(\mathrm{yr} B P)\end{array}$ & $\begin{array}{l}\text { Error } \\
(1 \sigma)\end{array}$ & Chi-squared test & Reference \\
\hline Margaux Cave & $\begin{array}{l}\text { GifA } 92354 \\
\text { GifA } 92355 \\
\text { GifA } 92362 \\
\text { OxA-3533 } \\
\text { OxA-3534 }\end{array}$ & $\begin{array}{l}\text { bone } \\
\text { bone } \\
\text { bone } \\
\text { bone } \\
\text { bone } \\
\text { average }\end{array}$ & $\begin{array}{l}9590 \\
9530 \\
9260 \\
9530 \\
9350 \\
\mathbf{9 4 6 0}\end{array}$ & $\begin{array}{r}110 \\
110 \\
120 \\
120 \\
120 \\
\mathbf{5 0}\end{array}$ & $5.76 / \chi^{2}{ }_{5 ; 0.05}=9.49$ & \\
\hline Flageolet & $\begin{array}{l}\text { GifA } 95538 \\
\text { GifA } 95559 \\
\text { OxA-598 }\end{array}$ & $\begin{array}{l}\text { bone } \\
\text { bone } \\
\text { bone } \\
\text { average }\end{array}$ & $\begin{array}{l}32040 \\
34300 \\
33800 \\
\mathbf{3 3 0 0 0}\end{array}$ & $\begin{array}{r}850 \\
1100 \\
1800 \\
\mathbf{6 3 0}\end{array}$ & $2.87 / \chi_{3 ; 0.05}^{2}=5.99$ & Delpech \& Riguad 2001 \\
\hline Combe Saumière & $\begin{array}{l}\text { GifA } 96768 \\
\text { OxA-6507 }\end{array}$ & $\begin{array}{l}\text { bone } \\
\text { bone } \\
\text { average }\end{array}$ & $\begin{array}{l}35500 \\
34000 \\
\mathbf{3 4 5 6 0}\end{array}$ & $\begin{array}{r}1100 \\
850 \\
670\end{array}$ & $1.16 / \chi^{2} 2 ; 0.05=3.84$ & Delpech \& Riguad 2001 \\
\hline
\end{tabular}

The 2 tests show the good correlation between the ${ }^{14} \mathrm{C}$ ages of the ninhydrin-treated bones and those of samples collected at the same archeological level (Figure 4) for time intervals ranging between $9000-45,000 \mathrm{yr}$ BP. All these comparisons confirm the reliability and accuracy of the method for dates up to $45,000 \mathrm{yr}$ BP.

\section{CONCLUSION}

In this paper, we described our routine protocol of bone pretreatment for AMS ${ }^{14} \mathrm{C}$ dating. This routine is applied to fossil bones containing more than $0.2 \%$ of nitrogen in whole bone.

The blank level is a function of the mass of the carbon sample. According to the equation ( $\mathrm{y}=$ $119.68 / \mathrm{x}+0.1295)$, the blank value is equal to $0.20 \pm 0.08 \mathrm{pMC}(\geq 50,000 \mathrm{yr} \mathrm{BP})$ for a sample mass of $1500 \mu \mathrm{g}$ and $0.37 \pm 0.10 \mathrm{pMC}(\geq 45,000 \mathrm{yr} \mathrm{BP})$ for a sample mass of $500 \mu \mathrm{g}$. The contamination by modern carbon is attributed either to the difficulty of degassing the sample or to the introduction of atmospheric $\mathrm{CO}_{2}$.

The validity of the method and the protocol is tested by comparing the ${ }^{14} \mathrm{C}$ ages obtained on bones by this method and those obtained by other methods (Oxford and Groningen bone methods or associated materials). The satisfactory results of these comparisons and the good estimation of the blank level show the reliability and accuracy of the method for dates up to 45,000 $\mathrm{yr}$ BP. 


\section{ACKNOWLEDGMENTS}

We gratefully acknowledge M Paterne for helpful comments and discussions. We thank M Otte for providing the Sclayn samples and $\mathrm{H}$ Bocherens for his help in selecting the Sclayn bones. The Gerde sample was provided by the late A Clot. We wish to thank M Fontugne for the Kozarnika results, the members of the ${ }^{14} \mathrm{C}$ laboratory (LSCE), and the staff of Gif-sur-Yvette Tandetron Facility (UMS 2004). This work was supported by the French CNRS and the CEA, LSCE contribution nr 1001.

\section{REFERENCES}

Ajie HO, Kaplan IR, Hauschka PV, Kirner D, Slota PJ, Taylor J, Taylor RE. 1992. Radiocarbon dating of bone osteocalcin: isolating and characterizing a noncollagen protein. Radiocarbon 34(3):296-305.

Ambrose SH. 1990. Preparation and characterization of bone and tooth collagen for isotopic analysis. Journal of Archaeological Science 17:431-51.

Ambrose SH. 1993. Isotopic analysis of paleodiets: methodological and interpretive considerations. In: Sandford MK, editor. Investigations of ancient human tissue. Amsterdam: Gordon and Breach Science Publishers. p 59-130.

Arnold JR, Libby WF. 1951. Radiocarbon dates. Science 113:111-20.

Arnold M, Bard E, Maurice P, Valladas H, Duplessy JC. 1989. ${ }^{14} \mathrm{C}$ dating with the Gif-sur-Yvette Tandetron accelerator: status report and study of isotopic fractionation in the sputter ion source. Radiocarbon 31:284 91.

Bocherens H, Billiou D, Patou-Mathis M, Bonjean D, Otte M, Mariotti A. 1997. Paleobiological implications of the isotopic signatures $\left({ }^{13} \mathrm{C},{ }^{15} \mathrm{~N}\right)$ of fossil mammal collagen in Scladina Cave (Sclayn, Belgium). Quaternary Research 48:370-80.

Bocherens H, Tresset A, Wiedmann F, Giligny F, Lafage F, Lanchon Y, Mariotti A. 1997. Diagenetic evolution of mammal bones in two French Neolithic sites. Bulletin de la Société géologique France 168:5.

Brown TA, Nelson DE, Vogel JS, Southon JR. 1988. Improved collagen extraction by modified Longin method. Radiocarbon 30(2):171-7.

Brown TA, Southon JR. 1997. Corrections for contamination background in AMS ${ }^{14} \mathrm{C}$ measurements. $\mathrm{Nu}$ clear Instruments and Methods in Physics Research B123:208-13.

Clot A. 1987. La grotte de Gerde (Hautes-Pyrénées), site préhistorique et paléontologique. Tarbes: Société Ramond.

Debenham NC. 1998. Thermoluminescence dating of stalagmitic calcite from la grotte Scladina at Sclayn (Namur). In: Otte M, Patou-Mathis M, Bonjean D, editors. Recherches aux grottes de Sclayn, Volume 2. Liège: L'Archéologie ERAUL:39-43.

Delpech F, Rigaud J-P. 2001. Quelques exemples sur l'apport des datations en archéologie préhistorique. In: Barrandon J-N, Guibert P, Michel V, editors. Datation $X X I^{e}$ rencontres internationales d'archéologie et d'histoire d'Antibes. Antibes: APDCA. p 315-31.

Fontugne MR, Tisnérat-Laborde N. Forthcoming. Une séquence du Paléolithique inférieur au Paléolithique récent dans les Balkans: La grotte de Kozarnika à Orechets (Nord ouest de la Bulgarie). Datations radiocarbone.

Gillespie R, Hedges REM, Humm MJ. 1986. Routine AMS dating of bone and shell proteins. Radiocarbon 28(2A):451-6.

Gillespie R, Hedges REM, Wand JO. 1984. Radiocarbon dating of bone by accelerator mass spectrometry. Journal of Archaeological Science 11:165-70.

Gurfinkel DM. 1987. Comparative study of the radiocarbon dating different bone collagen preparations. $R a$ diocarbon 29(1):45-52.

Hedges REM, Law IA, Bronk CR, Housley RA. 1989. The Oxford Accelerator Mass Spectrometry Facility: technical developments in routine dating. Archaeometry 31(2):99-113.

Hedges REM, Millard AR. 1995. Measurements and relationships of diagenetic alteration of bone from three archaeological sites. Journal of Archaeological Science 22:201-9.

Hedges REM, van Klinken GJ. 1992. A review of current approaches in the treatment of bone for radiocarbon dating by AMS. Radiocarbon 34(3):279-91.

Kirner DL, Taylor RE, Southon JR. 1995. Reduction in backgrounds of microsamples for AMS ${ }^{14} \mathrm{C}$ dating. Radiocarbon 37(2):697-704.

Kretschmer W, Anton G, Benz M, Blasche S, Erler G, Finckh E, Fischer L, Kerscher H, Kotva A, Klein M, Leigart M, Morgenroth G. 1998. The Erlangen AMS Facility and its application in ${ }^{14} \mathrm{C}$ sediment and bone dating. Radiocarbon 40(1):231-8.

Law IA, Hedges REM. 1989. A semi-automated bone pretreatment system and the pretreatment of older and contaminated samples. Radiocarbon 31(3):247-53.

Long A, Wilson AT, Ernst RD, Gore BH, Hare PE. 1989. AMS radiocarbon dating of bones at Arizona. Radiocarbon 31(3):231-8.

Longin R. 1971. New method of collagen extraction for radiocarbon dating. Nature 230:241-2.

Moore S, Stein WH. 1950. Photometric ninhydrin method for use in the chromatography of amino acids. Journal of Biological Chemistry 176:367-88.

Nelson DE. 1991. A new method for carbon isotopic analysis of protein. Science 251:552-4. 
Redvers-Newton NA, Coote GE. 1994. Bone pretreatments for radiocarbon dating: a study incorporating AMS dating and ion beam analysis. Nuclear Instruments and Methods in Physics Research B 92:270-3.

Roque C, Guibert P, Vartanian E, Bechtel F, Oberlin C, Evin J, Mercier N, Valladas H, Texier J-P, Rigaud J-P, Delpech F, Cleyet-Merle J-J, Turq A. 2001. Une expérience de croisement de datations $\mathrm{TL} /{ }^{14} \mathrm{C}$ pour la séquence solutréenne de Laugerie-Haute, Dordogne. In: Barrandon J-N, Guibert P, Michel V, editors. Datation XXI rencontres internationales d'archéologie et d'histoire d'Antibes. Antibes: APDCA. p 217-32.

Schleicher M, Grootes PM, Nadeau M-J, Schoon A. 1998. The carbonate ${ }^{14} \mathrm{C}$ background and its components at the Leibniz AMS Facility. Radiocarbon 40(1):85-93.

Stafford TW, JR., Brendel K, Duhamel RC. 1988. Radio- carbon, ${ }^{13} \mathrm{C}$ and ${ }^{15} \mathrm{~N}$ analysis of fossil bone: removal of humates with XAD-2 resin. Geochemica at Cosmochimica Acta 52:2257-67.

Tisnérat-Laborde N, Poupeau J-J, Tannau J-F, Paterne M. 2001. Development of a semi-automated system for routine preparation of carbonate sample. Radiocarbon 43(2A):299-304.

van Klinken GJ, Mook WG. 1990. Preparative high-performance liquid chromatographic separation of individual amino acids derived from fossil bone collagen. Radiocarbon 32(2):155-64.

Vogel JS, Nelson DE, Southon JR. 1987. ${ }^{14} \mathrm{C}$ background levels in an accelerator mass spectrometry system. $R a$ diocarbon 29(3):323-33.

Ward GK, Wilson SR. 1978. Procedures for comparing and combining radiocarbon age determinations: a critique. Archaeometry 20(1):19-31. 